\title{
Effects of quercetin on the nicotine-induced oxidative status in male Wistar rats: study on c-reactive protein (CRP) and malondialdehyde (MDA) concentrations
}

\author{
Deri Riskiyanti Tallo Manafe ${ }^{1}$, Denny Agustiningsih ${ }^{2}$, Prasetyastuti ${ }^{3}$ \\ ${ }^{1}$ Postgraduate Program of Basic Medical and Biomedical Sciences, ${ }^{2}$ Department of \\ Physiology, ${ }^{3}$ Department of Biochemistry, Faculty of Medicine, Universitas Gadjah Mada, \\ Yogyakarta
}

DOI: http://dx.doi.org/10.19106/JMedSci004802201602

\begin{abstract}
Nicotine can cause atherosclerosis by activating nuclear factor- $\mathrm{KB}$ (NF- $\mathrm{KB}$ ) pathway lead to induce proinflammatory cytokines release as C-reactive protein (CRP) main regulators. The increase of CRP can induce reactive oxygen species (ROS) and increase of malondialdehyde (MDA). Quercetin has been proven to have antiinflammatory and antioxidant effects. This study was conducted to evaluate effect of quercetin on serum CRP and MDA concentrations in rats induced by nicotine. This was a true experimental study with post test only control group design. Thirty six of male Wistar rats were divided into six groups. Group I as normal control received $1 \mathrm{~mL} / \mathrm{kg} \mathrm{BW}$ of $\mathrm{NaCl} 0.9 \%$ solution. Group II as negative control received $2 \mathrm{mg} / \mathrm{kg}$ BW of nicotine and Group III as positive control received $2 \mathrm{mg} / \mathrm{kg} \mathrm{BW}$ of nicotine and atorvastatin at dose of $5 \mathrm{mg} / \mathrm{kg} \mathrm{BW}$. Group IV-VI as treatment groups received $2 \mathrm{mg} / \mathrm{kg}$ BW of nicotine and quercetin at dose of 25; 50 or $100 \mathrm{mg} / \mathrm{kg} \mathrm{BW}$, respectively. Nicotine was given subcutaneously whereas atorvastatin and quercetin were given orally once per day for 28 days, consecutively. Serum CRP and MDA concentrations were measured using Rat hs-CRP ELISA kit and TBARS assay kit, respectively. Data were analyzed using analysis of variance (ANOVA) continued using LSD post-hoc test. The results showed that quercetin reduced serum CRP and MDA concentrations in dose dependent manner. Serum CRP concentration on Group V (173.39 $\pm 34.85 \mathrm{ng} / \mathrm{mL})$ and Group VI $(114.15 \pm 43.62 \mathrm{ng} / \mathrm{mL})$ were significantly lower than that Group II $(244.77 \pm 37.95 \mathrm{ng} / \mathrm{mL})(\mathrm{p}<0.05)$. Furthermore, serum MDA concentration on Group IV (5.95 $\pm 0.11 \mathrm{mmol} / \mathrm{mL})$, Group V $(3.93 \pm 0.09 \mathrm{mmol} / \mathrm{mL})$ and Group VI ( $2.14 \pm 0.09 \mathrm{mmol} / \mathrm{mL})$ were significantly lower than that Group II $(7.29 \pm$ $0.06 \mathrm{mmol} / \mathrm{mL})(\mathrm{p}<0.05)$. In conclusion, quercetin reduces the nicotine-induced oxidative status in rats.
\end{abstract}

\section{ABSTRAK}

Nikotin dapat menyebabkan atherosclerosis dengan mengaktifkan jalur nuclear factor$\kappa B(N F-\kappa B)$ yang menginduksi pelepasan sitokin proinflamasi sebagai regulator utama C-reactive protein (CRP). Kenaikan CRP dapat menginduksi reactive oxygen species (ROS) dan meningkatkan malondialdehid (MDA). Quersetin terbukti memiliki efek antiinflamasi 
dan antioksisdan. Penelitian ini dilakukan untuk mengkaji efek quersetin terhadap kadar serum CRP dan MDA tikus yang diinduksi nikotin. Penelitian ini merupakan penelitian eksprimental murni menggunakan rancangan post test only control. Tiga puluh enam ekor tikus dibagi menjadi enam kelompok. Kelompok I sebagai control normal mnerima larutan $\mathrm{NaCl} 0.9 \% 1 \mathrm{ml} / \mathrm{kg} \mathrm{BB}$. Kelompok II sebagai control negatif menerima nikotik $2 \mathrm{mg} / \mathrm{kg}$ BB. Kelompok III sebagai control positif menerima nikotin $2 \mathrm{mg} / \mathrm{kg}$ BB dan atorvastatin $5 \mathrm{mg} / \mathrm{kg}$ BB. Kelompok IV-VI sebagai kelompok perlakuan menerima nikotin $2 \mathrm{mg} / \mathrm{kg}$ BB dan quersetin berturut-turut 25; 50 dan $100 \mathrm{mg} / \mathrm{kg}$ BB. Nikotin diberikan secara subkutan sedangkan atorvastatin dan quersetin diberikan secara oral. Kadar CRP dan MDA serum ditetapkan menggunakan Rat hs-CRP ELISA kit dan TBARS assay kit. Data yang diperoleh dianalisis dengan analisis varian (ANAVA) dilanjutkan dngan tes LSD post-hoc. Hasil penelitian menunjukkan quersetin menurunkan kadar CRP dan MDA yang tergantung dosis. Kadar CRP serum Kelompok V (173,39 $\pm 34,85 \mathrm{ng} / \mathrm{mL})$ dan Kelompok VI $(114,15 \pm 43,62 \mathrm{ng} / \mathrm{mL})$ lebih rendah secara nyata dari Kelompok II $(244,77 \pm 37,95$ $\mathrm{ng} / \mathrm{mL})(\mathrm{p}<0,05)$. Selajutnya, kadar MDA serum MDA pada Kelompok IV $(5,95 \pm 0,11$ $\mathrm{mmol} / \mathrm{mL})$, Kelompok V $(3,93 \pm 0,09 \mathrm{mmol} / \mathrm{mL})$ dan Kelompok VI $(2,14 \pm 0,09 \mathrm{mmol} /$ $\mathrm{mL})$ lebih endah secara nyata dari Kelompok II $(7,29 \pm 0,06 \mathrm{mmol} / \mathrm{mL})(\mathrm{p}<0,05)$. Dapat disimpulkan, quersetin menurunkan status oksidatif tikus yang diinduksi nikotin.

Keywords: quercetin - oxidative status - C-reactive protein - malondehaldehyde - nicotine

\section{INTRODUCTION}

Cigarette smoking has become an unhealthy life style almost all over the world. ${ }^{1}$ Concerning of one million smokers nowadays, there are about 500 thousand smokers who will die faster. The epidemiology studies estimated that 1 from 3 smokers died due to the cardiovascular disease., ${ }^{2,3}$ The main substance which has addictive characteristic in cigarette is nicotine. ${ }^{4,5}$ Nicotine exposure on smokers is anticipated to play a significant role in various cardiovascular diseases where endothelial dysfunction appears as the initial sign. Endothelial dysfunction represents the early sign of atherosclerosis disease which is known as inflammation disease on vascular wall. . $^{3,6-10}$

Nicotine can trigger the inflammation because it has direct effect on neutrophil and macrophage by activating nicotinic acetylcholine receptor (nAChR) on nerves cell and non nerves cell such as monocyte and endothelium. Nicotine binds to activated macrophage's nAChR, furthermore it will activate nuclear factor- $\kappa \mathrm{B}(\mathrm{NF}-\kappa \mathrm{B})$. The activation of NF- $\mathrm{KB}$ on macrophage causes the proliferation and migration of vascular smooth muscle cells (VSMC), the production of inflammatory mediators e.g. cyclooxygenase 2 (COX-2), prostaglandin E2 (PGE2), tumor necrosis factor- $\alpha$ (TNF- $\alpha)$, interleukin$1 \beta$ (IL-1 $\beta$ ), inducible nitric oxide synthase (iNOS), and also the expression of adhesion molecules. The release of proinflammatory cytokines to inflammatory sites will trigger the C-reactive protein (CRP) synthesis by macrophage. ${ }^{6,8}$

Synthesis of CRP triggers the increase of free radicals in the body which is known as oxidative stress. ${ }^{6}$ Oxidative stress can cause endothelial dysfunction by deactivating nitric oxide (NO) directly, thus it will decrease its bioavailability. It can happen due to superoxide anion $\left(\mathrm{O}_{2}^{-}\right)$which is one of the very reactive free radicals type that binds directly to $\mathrm{NO}$ and performs peroxynitric. ${ }^{11}$ Besides that, oxidative stress causes tetrahidropbiopterin (BH4) oxidation as one of the NO synthetic 
cofactor. This oxidation causes endothelial nitric oxide synthase (eNOS) uncoupling and results in the decrease of eNOS expression and NO production. ${ }^{12}$ Despite causing eNOS expression decrease, oxidative stress promotes endothelial cell membranes damage through the mechanism of lipid peroxidation formation marked by the increase of malondialdehyde (MDA) concentration in the body. ${ }^{13-15}$

Atherosclerosis disease induced by inflammation can be prevented by giving the antiinflammation and antioxidant treatments. Quercetin is a flavonol which is mostly found in fruits and vegetables such as apple, black tea, and onion. ${ }^{16,17}$ Quercetin has antiatherosclerosis and antithrombosis effects because of its ability as antioxidant, anti platelet, and antiinflammation. ${ }^{18}$ Quercetin as an antiinflammation works by blocking $\mathrm{NF}-\kappa \mathrm{B}$ signal, resulting in decreasing the protein inhibitor (I $\kappa \mathrm{B} \alpha$ and $\mathrm{I} \kappa \mathrm{B} \beta$ ) phosphorylation. ${ }^{19,20}$ It can degrade the NF- $\mathrm{KB}$ transcription factor and cytokines expression significantly so that it prevents the increase of CRP concentration. ${ }^{20}$ In addition, quercetin works as an antioxidant by catching ROS as the main cause of oxidative stress so that it can prevent NO production decrease and the increase of MDA concentration. ${ }^{21}$ This study was conducted to evaluate the effects of quercetin on the concentration of CRP and MDA in nicotine-induced male Wistar rats.

\section{MATERIALS AND METHODS}

\section{Chemicals}

Nicotine bitartrate dyhidrate was obtained from Nacalai Tesque Inc., Japan. Nicotine stock solution was prepared at concentration of $2 \mathrm{mg} / \mathrm{mL}$ in $\mathrm{NaCl} 0.9 \%$ solution. Atorvastatin and quercetin were obtained from Sigma-Aldrich, Singapore. Atorvastatin and quercetin stock solutions were prepared at concentration of $100 \mathrm{mg} / \mathrm{mL}$ in sodium carboxy methylcellulose (Na-CMC) $0.5 \%$ solution. All of the stock solutions were stored in glass bottle at $4{ }^{\circ} \mathrm{C}$ for no longer than 30 days.

\section{Animal and experimental design}

This is a true experimental study with post test only control group design. Thirty six male Wistar rats whose weight ranged between 100 and $150 \mathrm{~g}$ and age of 5 weeks obtained from the Integrated Research and Testing Laboratory (LPPT), Universitas Gadjah Mada were used in this study. The rats were housed in individual cages that were well ventilated under 12-hour cycles of light and dark condition at room temperature. They were fed a standard food and provided free access to water ad libitum. After acclimatization period of one week, the rats were divided into six groups with 6 rats in each group. Group $\mathrm{I}$ as normal control received $1 \mathrm{~mL} / \mathrm{kg} \mathrm{BW}$ of $\mathrm{NaCl} 0.9 \%$ solution. Group II as negative control received $2 \mathrm{mg} / \mathrm{kg} \mathrm{BW}$ of nicotine and Group III as positive control received $2 \mathrm{mg} /$ $\mathrm{kg} \mathrm{BW}$ of nicotine and atorvastatin at dose of $5 \mathrm{mg} / \mathrm{kg}$ BW. Group IV-VI as treatment groups received $2 \mathrm{mg} / \mathrm{kg} \mathrm{BW}$ of nicotine and quercetin at dose of $25 ; 50$ or $100 \mathrm{mg} /$ $\mathrm{kg} \mathrm{BW}$, respectively. The nicotine dosage was freshly prepared in $\mathrm{NaCl} 0.9 \%$ solution and subcutaneously injected once per day for 28 days consecutively at 11.00 AM. Whereas, the atorvastatin and quercetin dosages were freshly prepared in Na-CMC $0.5 \%$ solution and orally administered once per day for 28 days consecutively, 3 hours before nicotine injection (at 08.00 AM).

\section{Serum CRP and MDA examinations}

On day 35, three hours after the last intervention, rats were anesthesized using 
ketamine and diazepam subcutaneously and then were fixated. Blood samples were collected from the rats and placed to the freezer for over 2 hours at room temperature or overnight at $4{ }^{\circ} \mathrm{C}$. The blood samples were then homogenised and centrifuged for $20 \mathrm{~min}$ at $3000 \mathrm{~g}$. Serum samples were then collected and stored at $-80{ }^{\circ} \mathrm{C}$ until analysis. Serum CRP concentration was measured by using Rat hs-CRP ELISA kit, whereas serum MDA concentration was measured by using 2-thiobarbituric acid reactive substances (TBARS) assay kit.

\section{Data analysis}

Data of serum CRP and MDA concentrations were expressed as mean \pm standard deviation (SD) and analyzed by using analysis of variance (ANOVA) continued by least significant difference (LSD) post-hoc test. A $p$ value less than 0.05 was considered significant.

\section{RESULTS}

Serum CRP and MDA concentrations of all groups are presented in TABLE 1. After nicotine induction at dose of $2 \mathrm{mg} / \mathrm{kg} \mathrm{BW}$ for 28 days (Group II), serum CRP (244.77 \pm $37.95 \mathrm{ng} / \mathrm{mL})$ and MDA (7.29 $\pm 0.06 \mathrm{mmol} /$ $\mathrm{mL}$ ) concentrations of the rats increased significantly compared to those without nicotine induction on Group I (serum CRP concentration was $73.78 \pm 20.94 \mathrm{ng} / \mathrm{mL}$ and serum MDA concentrations was $0.94 \pm 0.03$ $\mathrm{mmol} / \mathrm{mL})(\mathrm{p}<0.05)$. After nicotine induction at dose of $2 \mathrm{mg} / \mathrm{kg} \mathrm{BW}$ and quercetin administrations at dose of 25; 50 and $100 \mathrm{mg} /$ $\mathrm{kg} \mathrm{BW}$ for 28 days (Group IV-VI), serum CRP concentration on Group V $(173.39 \pm 34.85 \mathrm{ng} /$ $\mathrm{mL})$ and Group VI $(114.15 \pm 43.62 \mathrm{ng} / \mathrm{mL})$ significantly reduced compared to Group II $(\mathrm{p}<0.05)$. Moreover serum MDAconcentration on Group IV $(5.95 \pm 0.11 \mathrm{mmol} / \mathrm{mL})$, Group $\mathrm{V}(3.93 \pm 0.09 \mathrm{mmol} / \mathrm{mL})$ and Group VI (2.14 $\pm 0.09 \mathrm{mmol} / \mathrm{mL}$ ) also significantly reduced compared to that Group II $(\mathrm{p}<0.05)$. After nicotine induction at dose of $2 \mathrm{mg} / \mathrm{kg} \mathrm{BW}$ and atorvastatin administration at dose of 5 $\mathrm{mg} / \mathrm{kg} \mathrm{BW}$ (Group III), serum CRP (166.65 $\pm 19.06 \mathrm{ng} / \mathrm{mL})$ and MDA $(3.02 \pm 0.10 \mathrm{mmol} /$ $\mathrm{mL})$ concentrations also significantly reduced compared to that Group II ( $\mathrm{p}<0.05)$.

TABLE 1. Serum CRP and MDA concentration in each group

\begin{tabular}{lccc}
\hline \multicolumn{1}{c}{ Group } & $\mathrm{n}$ & $\begin{array}{c}\text { Serum CRP } \\
(\mathrm{ng} / \mathrm{mL})\end{array}$ & $\begin{array}{c}\text { Serum MDA } \\
(\mathrm{nmol} / \mathrm{mL})\end{array}$ \\
\hline I (normal) & 6 & $73.78 \pm 20.94$ & $0.94 \pm 0.03$ \\
II (nicotine) & 6 & $244.77 \pm 37.95$ & $7.29 \pm 0.06$ \\
III (nicotine + atorvastatin 5 mg/kgBW) & 6 & $166.65 \pm 19.06^{\mathrm{a}, \mathrm{b}}$ & $3.02 \pm 0.10^{\mathrm{a}, \mathrm{b}}$ \\
IV (nicotine + quercetin 25 mg/kgBW) & 6 & $241.87 \pm 40.30^{\mathrm{b}}$ & $5.95 \pm 0.11^{\mathrm{a}, \mathrm{b}}$ \\
V (nicotine + quercetin 50 $\mathrm{mg} / \mathrm{kgBW})$ & 6 & $173.39 \pm 34.85^{\mathrm{a}, \mathrm{b}}$ & $3.93 \pm 0.09^{\mathrm{a}, \mathrm{b}}$ \\
VI (nicotine + quercetin $100 \mathrm{mg} / \mathrm{kgBW})$ & 6 & $114.15 \pm 43.62^{\mathrm{a}, \mathrm{b}}$ & $2.14 \pm 0.09^{\mathrm{a}, \mathrm{b}}$ \\
\hline
\end{tabular}

${ }^{\mathrm{a}}$ significantly lower than Group II $(\mathrm{p}<0.05)$; ${ }^{\mathrm{b}}$ significantly higher than Group I $(\mathrm{p}<0.05)$. 
Correlation between quercetin doses and serum CRP and MDA concentrations on rats after nicotine induction was also evaluated by using Pearson test of correlation. Negative significantly correlation was observed between quercetin doses and serum CRP and MDA concentrations (TABLE 2).

TABLE 2. Correlation between quercetin doses and serum CRP and MDA concentrations on rats after nicotine induction

\begin{tabular}{lcc}
\hline Correlation & $\mathrm{r}$ & $\mathrm{p}$ \\
\hline $\begin{array}{l}\text { Quercetin doses vs CRP } \\
\text { concentration }\end{array}$ & -0.506 & 0.032 \\
$\begin{array}{l}\text { Quercetin doses vs MDA } \\
\text { concentration }\end{array}$ & -0.622 & 0.006 \\
\hline
\end{tabular}

\section{DISCUSSION}

Endothelial cells have anticoagulant and antithrombotic activities. They also regulate various mediators including NO which is known as endothelium derived relaxing factor (EDRF). NO is synthesized from L-arginine by endothelial nitric oxide synthase (eNOS) in endothelium. NO plays an important role in regulating wide spectrum of cardiovascular functions including mediating vasorelaxation, inhibiting leukocytes-endothelial adhesion and preventing platelet aggregation., ${ }^{7,23}$ Decrease in NO production caused by endothelial dysfunction can lead to an early sign of various cardiovascular diseases such as atherosclerosis. ${ }^{6,11}$

Inflammation has an important role in the process of atherosclerosis plaque growth until thrombosis occurs that is caused by rupture. ${ }^{9,25,26}$ Macrophage located in the plaque contributes to the atherosclerosis occurrence by activating NF- $\kappa \mathrm{B}$ to stimulate proinflammatory genes production. ${ }^{5}$ Release of proinflammatory cytokines such as IL-6, IL- 1 , and TNF- $\alpha$ shows the main regulators from CRP, thus CRP concentration in the body stand for the indicator of a non specific systemic inflammation. ${ }^{9}$

Nicotine can trigger the release of CRP through nAChR in the macrophage which located at atherosclerosis plaque. Synthesized CRP triggers the increase of free radicals which is known as oxidative stress. ${ }^{6}$ Oxidative stress can degrade the NO production by deactivating it so that it decreases the NO bioavailability. ${ }^{11}$ In addition, oxidative stress causes oxidation of $\mathrm{BH} 4$ as one of the $\mathrm{NO}$ synthetic cofactor. It causes uncoupling of eNOS and results in decreasing the expression of eNOS and NO production. ${ }^{12}$ Oxidative stress also triggers formation of lipid peroxidation which damages endothelial cell membranes, as marked by the increase of MDA concentration in the body. ${ }^{13,14}$

The result indicated that the nicotine administration increased the serum CRP concentration as showed the significantly higher serum CRP concentration after nicotine induction (Grou II) compared to without nicotine induction (Group I) $(\mathrm{p}<0.05)$. This result is in accordance with previous study which showed that nicotine induction at dose of $2 \mathrm{mg} / \mathrm{kg}$ BW cause endothelial dysfunction as indicated by the increase of serum CRP concentation. ${ }^{5,6,26,27}$ Nicotine stimulates the production of the inflammatory mediators such as IL-6, IL-1 and TNF- $\alpha$ as main regulator of CRP. Moreover, nicotine induces of CRP production of macrophage by activating the transcription factor NF- $\kappa \mathrm{B} .{ }^{6}$

Furthermore, this result also indicated that quercetin administration could inhibit the increase serum CRP concentration induced by nicotine in dose dependent manner (Table 1). Although, the serum CRP concentration after quercetin administration at highest dose (100 mg/kg BW on Group VI) was higher than that without nicotine induction 
on Group I. However, this effect of quercetin was significantly higher than atorvastatin as positive control at dose of $5 \mathrm{mg} / \mathrm{kg} \mathrm{BW}$ (Group III). It was indicated that the quercetin administration at dose $100 \mathrm{mg} / \mathrm{kg} \mathrm{BW}$ had not prevented inflammation due to nicotine induction, yet. Previous study reported that quercetin reduced the expression of human CRP and cardiovascular risk factors in mice in vivo. ${ }^{19}$ It was also reported that quercetin reduced serum level of both TNF- $\alpha$ and CRP in models of diabetes. ${ }^{20}$

The effect of quercetin on serum CRP concentration after nicotine induction was parallel with its effect on serum MDA concentration. Quercetin administration could also inhibit the increase serum MDA concentration induced by nicotine in dose dependent manner (Table 1 and 2). Previous studies reported that nicotine induction at the dose of $2 \mathrm{mg} / \mathrm{kg}$ BW could stimulate inflammation and oxidative stress lead to an endothelial dysfunction resulting the increase serum MDA concentration. 6,7,26,27 Furthermore, it was reported that quercetin has antiinflammatory and antioxidant effects which may inhibit the inflammation and oxidative stress induced by nicotine. ${ }^{19,20,21}$

\section{CONCLUSION}

It can be concluded that quercetin reduces the oxidative status in rats induced by nicotine as indicated by the decrease of serum CRP and MDA concentrations after quercetin administration. Further study will be conducted to evaluate the mechanism of actions of quercetin in the reduce of oxidative status.

\section{ACKNOWLEDGMENTS}

We would like to thank dr. AA Heru Tjahyono, SpOG as former Dean of Faculty of Medicine, Universitas Cendana, Kupang,
East Nusa Tenggara for their support during the study. We would also like to thank Mr. Yuli from Center for Food and Nutrition Studies, Mrs. Rumbiwati from Department Parasitology and Mr. Yunadir and Mrs. Agustin from Department of Anatomy Pathology, Faculty of Medicine, Universitas Gadjah Mada, Yogyakarta for their valuable assistances during laboratory works.

\section{REFERENCES}

1. Sopori M. Effects of cigarette smoke on the immune system. Nature Rev Immun 2002; 2(5):372-7. http://dx.doi.org/doi:10.1038/ nri803

2. Tonstad S, Cowan JL. C-reactive protein as a predictor of disease in smokers and formers: a review. J Clin Pract 2009; 63(11):1634-41. http://dx.doi.org/10.1111 j.1742-1241.2009.02179. x

3. Rodella LF, Favero G, Rossini C, Foglio E, Reiter RJ, Rezzani R. Endothelin-1 as a potential marker of melatonin's therapeutics effects in smoking-induced vasculopathy. Life Sci 2010; 87(17-18):558-64. http:// dx.doi.org/10.1016/j.1fs.2010.09.011

4. Joukar S, Shahouzehi B, Najafipour H, Gholamhoseinian A, Joukar F. Ameliorative effect of black tea on $\mathrm{n}$ icotine induced cardiovascular pathogenesis in rat. EXCLI J 2012; 11:309-17.

5. Mao J, Liu J, Pang X, Li M, Song J, Han $\mathrm{C}$, et al. Nicotine induces the expression of C-Reactive protein via MAPK-dependent signal pathway in U937 macrophages. Mol Cells 2012; 3494):457-61. http://dx.doi. org/10.1007/s10059-012-0205-0

6. Jialal I, Devaraj S, Venugopal SK. C-reactive protein: risk marker or mediator in atherothrombosis? Hypertension 2004; 44(1):6-11. http://dx.doi.org/ 10.1161/01 . HYP.0000130484.20501.df 
Manafe et al., Effects of quercetin on the nicotine-induced oxidative status in male Wistar rats: study on c-reactive protein (CRP) and malondialdehyde (MDA) concentrations

7. Balakumar P, Jindal S, Shah DI, Singh M. Experimental models for vascular endothelial dysfunction. Trends Med Res 2007; 2(1):1220. http://dx.doi.org/10.3923/ tmr.2007.12.20

8. Stirban A, Nandrean S, Kirana S, Gotting C, Veresiu IA, Tschoepe D. Benfotiamine counteracts smoking-induced vascular dysfunction in healthy smokers. Int J Vasc Med 2012; 2012:968761. http://dx.doi. org/10.1155/968761

9. Li M, Liu JT, Pang XM, Han CJ, Mao JJ. Epigalloctechin-3-gallate inhibits angiotensin II and interleukin-6-induced C-reactive protein production in macrophages. Pharmacol Reports 2012; 64(4):912-8.

10. Williams TN, Zhang CX, Game BA, He L, Huang Y. C-reactive protein stimulates MMP-1 expression in U937 histiocytes through FcyRII and extracellular signalregulated kinase pathway:: an implication of CRP involvement in plaque destabilization. Arterioscler Thromb Vasc Biol 2004; 24(1):61-6. $\quad$ http://dx.doi.org/10.1161/ 01.ATV.0000104014.24367.16

11. Landmesser U, Dikalov S, Price RS, McCann L, Fukai T, Holland SM, et al. Oxidation of tetrahydrobiopterin leads to uncoupling of endothelial cell nitric oxide synthase in hypertension. J Clin Invest 2003; 111(8):12019. http://dx.doi.org/10.1172/JCI14172

12. Kuzkaya N, Weissmann N, Harrison DG, Dikalov S. Interactions of peroxynitrite, tetrahydrobiopterin, ascorbic acid, and thiols: implications for uncoupling endothelial nitric-oxide synthase. J Biol Chem 2003; 278(25):22546-54. http://dx.doi.org/10.1074/ jbc.M302227200

13. Behrendt D, Ganz P. Endothelial function: from vascular biology to clinical applications. Am J Cardiol 2002; 90(10C):40-8.

14. Afanas'ev I. ROS and RNS signaling in heart disorders: could antioxidant treatment be successful?. Oxi Med Cell Longev 2011;
2011:293769. http://dx.doi.org/10.1155/ 2011/293769

15. Böhm F, Pernow J. The importance of endothelin-1 for vascular dysfunction in cardiovascular disease. Cardiovasc Res 2007; 76(1):8-18. http://dx.doi.org/10.1016/j. cardiores.2007.06.004

16. Askari G, Ghiasvand R, Feizi A, Ghanadian SM, Karimian J. The effect of quercetin supplementation on selected markers of inflammation and oxidative stress. J Res Med Sci 2012; 17:637-41.

17. Erlund I. Review of the flavonoids quercetin, hesperetin, and naringenin. dietary sources, bioactivities, bioavailability, and epidemiology. Nut Res 2004; 24(10):851-74. http://dx.doi.org/10.1016/j. nutres.2004.07.005

18. Oh WJ, Endale M, Park SC, Cho JY, Rhee $\mathrm{MH}$. Dual role of quercetin in platelets: phosphoinositide-3-kinase and MAP kinase inhibition, and cAMP-dependent vasodilatorstimulated phosphoprotein stimulation. Evid Based Complement Alternat Med 2012; 2012:485262. http://dx.doi. org/10.1155/485262.

19. Kleemann R, Verschuren L, Morrison M, Zadelaar S, van-Erk MJ, Wielinga PY, et al. Antiinflammatory, antiproliferative and antiatherosclerotic effects of quercetin in human in vitro and in vivo models. Atherosclerosis 2011; 218(1):44-52. http://dx.doi.org/10.1016/j. atherosclerosis.2011.04.023

20. Mahmoud MF, Hassan NA, El-Bassossy HM, Fahmy A. Quercetin protects against diabetesinduced exaggerated vasoconstriction in rats: effect on low grade inflammation. PLoS one 2013; 8(5):63784. http://dx.doi.org/10.1371/ journal.pone. 0063784

21. Cos P, Ying L, Calomme M, Hu JP, Cimanga $\mathrm{K}$, Van Poel B, et al. Structure-activity 
relationship and classification of flavonoids as inhibitors of xanthine oxidase and superoxide scavengers. J Nat Prod 1998; 61(1):71-6. http://dx.doi.org/10.1021/ np970237h

22. Ionica FE, Mota M, Pisoschi C, Popescu F, Gofita E. Statins therapy, C-reactive protein (CRP) levels and type 2 diabetes. Curr Health Sci J 2009; 35(2):87-91.

23. Brunner H, Cockcroft JR, Deanfield J, Donald A, Ferrannini E, Halcox J, et al. Endothelial function and dysfunction. Part II: Association with cardiovascular risk factors and disease : A statement by the working group on endothelins and endothelial factors of the european society of hypertension. $\mathrm{J}$ Hypertens 2005; 23(2):233-46.

24. Chen Y, Wang J, Yao Y, Yuan W, Kong M, Lin $Y$, et al. CRP regulates the expression and activity of tissue factor as well as tissue factor pathway inhibitor NF- $\kappa$ B and ERK $1 / 2$ MAPK pathway. FEBS Lett 2009; 583(17):28118. http://dx.doi.org/0.1016/ j.febslet. 2009. 07.037

25. Ambrose JA, Barua RS. The pathophysiology of cigarette smoking and cardiovascular disease an update. J Am Coll Cardiol 2004; 43(10):1731-7. http://dx.doi.org/10.1016/j. jacc.2003.12.047

26. Luo HL, Zang WJ, Lu J, Yu XJ, Lin YX, et al. The protective effect of captopril on nicotineinduced endothelial dysfunction in rat. Basic Clin Pharmacol Toxicol 2006; 99(3):237-45. http://dx.doi.org/10.1111/j.1742-7843.2006. pto_494.x

27. Chakkarwar VA. Fenofibrate attenuates nicotine-induced vascular endothelial dysfunction in the rat. Vascul Pharmacol 2011; 55(5-6):163-8. http://dx.doi.org/10.1016/j. vph.2011.08.215 